\title{
FRACASTORO AND HENLE: A RE-APPRAISAL OF THEIR CONTRIBUTION TO THE CONCEPT OF COMMUNICABLE DISEASES
}

\author{
by
}

NORMAN HOWARD-JONES1

IT HAS BECOME part of the canon of medical history that Girolamo Fracastoro [Hieronymus Fracastorius] (1478-1553) and Jacob Henle (1809-1885) each made fundamental contributions, separated by three centuries, to the understanding of the role of living micro-organisms in the etiology of communicable diseases.

Fracastoro published his De contagione . . in $1546,{ }^{2}$ only three years after two works that are veritable cornerstones of biological and physical science: the $D e$ humani corporis fabrica . . . of Andreas Vesalius and the De revolutionibus . . . of Copernicus. The fundamental importance of both these works is incontestable, and claims have been made for De contagione that would seem to place it in the same category. For example, Fielding H. Garrison wrote in 1910 that it "contains the first scientific statement of the true nature of contagion, of infection, of disease germs and the modes of transmission of infectious diseases".

Later, Garrison asserted that Fracastoro "states with wonderful clairvoyance, the modern germ theory of disease". Arturo Castiglione, according to his English translator E. B. Krumbhaar, expressed the view that De contagione ... "best exhibits the scientific vision" of Fracastoro and "places him among the great biologists of his time". ${ }^{5}$ As will be seen later, it is very difficult to equate such statements with what Fracastoro actually wrote.

Henle's publication of 1840 on "miasms and contagions and on miasmaticcontagious diseases"' has won encomia that are no more restrained. For Müller and Prausnitz ${ }^{7}$ in 1905, this work showed Henle's "marvellous perspicacity", 8 and a

1 Norman Howard-Jones, O.B.E., M.R.C.S., L.R.C.P., Formerly Director, Division of Editorial and Reference Services, World Health Organization, Geneva, Switzerland. (Present address: 28 chemin Colladon, 1209 Geneva, Switzerland.) This paper is based on work done during the tenure in 1971-72 of an appointment as Visiting Scientist, National Library of Medicine, National Institutes of Health, Public Health Service, Department of Health Education and Welfare, USA.

2 H. Fracastorius, De sympathia et antipathia rerum. libri III. De contagione et contagiosis morbis et eorum curatione, English translation by W. C. Wright with parallel Latin text. New York, G. P. Putnam's Sons, 1930.

'Fielding H. Garrison, 'Fracastorius, Athanasius Kircher and the Germ Theory of disease', Science, 1910, 31: 500.

- Fielding H. Garrison, An introduction to the history of medicine, Philadelphia and London, 4th ed., W. B. Saunders, 1929.

- Arturo Castiglione, $A$ history of medicine. Translated from the Italian and edited by $E$. $B$. Krumbhaar, New York, Alfred A. Knopf, 1941.

- [J.] Henle, Pathologische Untersuchungen, Berlin, A. Hirschwald, 1840.

7 P. Th. Müller and W. Prausnitz, in Max Neuburger and Julius Pagel, Handbuch der Geschichte der Medizin, Jena, Gustav Fischer, Bd. 3, 1905.

B "bewunderungswürde Scharfsinn". 


\section{Norman Howard-Jones}

few years later Meyer-Steineg and Sudhoff wrote that it was "the first clear startingpoint for the recognition of the role of micro-organisms in the occurrence of communicable diseases."

Bulloch, in his superb history of bacteriology, affirmed that "Henle's statement ... contains all the elements habitually referred to as the 'postulates' of Koch. . . ."10 He supported this affirmation by reference to a paper of 1920 by Fildes and McIntosh. $\mathrm{He}$ also said that Henle "made a remarkable anticipation of the germ theory of disease". The long (twenty-four pages) paper by Fildes and McIntosh was an attempt to demonstrate by the application of Koch's postulates that the influenza pathogen was not a "filter-passer" but " $B$. influenzae", and the authors state categorically: "these are not Koch's postulates but Henle's". ${ }^{11}$ It is my contention that this statement is as groundless as was its authors' opinion on the nature of the influenza pathogen.

Castiglione believed Henle's essay (for it was nothing more) to be "the best prePasteurian statement of the micro-organismal causes of infectious disease", 12 and for Underwood Henle's contribution was "a noteworthy attempt to dispel the miasmatic fog". ${ }^{18}$ For Rosen, Henle's essay was "a landmark in the history of medicine in general and of infectious diseases in particular". ${ }^{14}$

I maintain that such claims on behalf both of Fracastoro and of Henle in respect of the theory of communicable diseases are unrealistic and grossly exaggerated. These claims are based on selective quotations, translation of terms that never corresponded to any objective reality by words that now refer to observed phenomena, and the application of hindsight to interpret in the language of experimental science what were only vague, and often manifestly incorrect, speculations. It remains to analyse exactly what ideas Fracastoro and Henle contributed to the concept of animate contagion and to what extent, in the case of Henle, the contribution constituted an innovation. Of the great importance of Henle's contributions in other fields there can be no doubt.

\section{WHAT FRACASTORO REALLY SAID}

Fracastoro did not distinguish between infection and contagion, but defined contagion as "an infection that passes from one thing to another". ${ }^{15} \mathrm{He}$ gave no indication of what he understood by "infection", but compared contagion to the

\footnotetext{
- Th. Meyer-Steineg and Karl Sudhoff, Geschichte der Medizin im Ü̈erblick mit Abbildungen, Jena, Gustav Fischer, 1921.

10 William Bulloch, The history of bacteriology, London, New York, Toronto, Oxford University Press, 1938.

11 P. Fildes and J. McIntosh, 'The aetiology of influenza', Brit. J. exp. Path., 1920, 1: 119-126; 159-174.

12 Castiglione, op. cit., note 5 above.

13 C. Singer and E. Ashworth Underwood, A short history of medicine, Oxford, Clarendon Press, 1962. (While described as the second edition of Charles Singer's work of 1928, this is in fact a new book.)

14 G. Rosen, 'Jacob Henle: on miasmata and contagia', Bull. Hist. Med., 1938, 6: 907.

1s In this and subsequent citations from Fracastoro, Wright's translation (note 2 above) has been used.
} 


\section{Fracastoro and Henle}

emanations of an onion: "Who could imagine that tears could be drawn from us, even from long distances, by onions and garlic....?" He referred to "the evaporations that occur in contagions", and often mentioned seminaria as conveying contagion. This term has usually been rendered in English as "germs", but the literal meaning of seminarium is a plantation or nursery. In the latter half of the eighteenth century, James Lind wrote of "a general seminary of contagion" with reference to a hospital crowded with infected patients, ${ }^{16}$ and this usage is much closer to the literal meaning of seminarium than the interpretation that has been given to Fracastoro's use of the term. What Fracastoro really understood by seminaria remains an enigma, but he believed that they had the power to propagate [propagare] and engender [gignere] themselves-“Just as the spirits do". [Presumably the animal spirits.] Whether this implied asexual reproduction or something akin to a chain reaction is quite unclear, but nowhere does Fracastoro specify that seminaria were living organisms. On the contrary, his speculations about them would seem to imply that they were not, for he said that they were "small imperceptible particles" that might be "hard" or "viscous", and that they were composed of "a combination of diverse elements". Typhus, according to Fracastoro, was "spread more by a taint in the air than by transmission from one person to another".

Fracastoro believed in the existence of a mythical animal which enjoyed the picturesque taxonomic designation catablepha, whose regard was supposed to kill at a distance of a mile. He compared contagions to poisons, or to "the animal called catablepha", and believed that there was "a certain kind of ophthalmia with which the sufferer infects everyone who looks at him". In the circumstances, it is rather remarkable that Castiglione should have stated that Fracastoro was "unhandicapped by superstition and tradition"! Elsewhere, Fracastoro draws a parallel between seminaria and "pepper, lime, euphorbium, pyrites, metals, and many other substances". He thought that certain constellations could portend the development of contagia, and that consumption of certain foods produced elephantiasis, scabies, and carbuncles. He attributed the English Sweating Sickness to vapours that arose from the soil, bringing with them "a subtle contagion which has analogy with the spirits or with the fine foam that floats on the surface of the blood". The seminaria of typhus were "not much removed from the nature of vapours", and while most people contracted syphilis by contagion "countless others have been affected without contagion". Astronomers had, said Fracastoro, predicted the arrival of syphilis as a new disease in Europe, and scabies could develop into leprosy, as leprosy could become elephantiasis.

That eminent medical historians could have taken all this rigmarole seriously is surely a matter for wonder. Probably no one would have been more astonished than Fracastoro himself to learn of the interpretations that have been read into his obscure notions.

\section{WHAT HENLE REALLY SAID}

Henle opened his treatise by pointing out that it contained "few facts and many

10 James Lind, An essay on the most effective means of preserving the health of seamen in the royal navy and a dissertation of fevers and infection, London, J. Murray, 1779. (The first edition was published in 1757). 
reflections". Had he said that it contained no facts and many speculations he would have been nearer the mark. He divided endemic and epidemic diseases into three classes: the first consisted of the purely miasmatic diseases that, as far as was known, never became contagious. Intermittent fever [malaria] was the only example given of this class. The second class was constituted by the "miasmatic-contagious" diseases. These originally arose miasmatically, but "evidently" also spread by contagion. They included contagious exanthemata, smallpox, measles, rubella, scarlatina, as also typhoid fevers, certain types of colds and catarrhs, influenza, diarrhoea, cholera, plague and one kind [not specified] of puerperal fever. All these diseases, Henle said, followed a typical course, which could neither be accelerated nor retarded. In between the first and second classes was an intermediate group, the gastric, catarrhal and rheumatic remitting fevers. In the third class were the "purely contagious diseases", which resulted only from contagion and never developed miasmatically. Contagions could be either fixed ( fixe) or volatile (flïchtige), and the third class of diseases resulted only from the former. This class included syphilis, scabies, some other "chronic skin rashes", rabies, and some other named animal diseases.

Henle stated that contagions could be excreted by the sick body-"I do not say, as it is usually expressed, produced in the sick body"-and transmitted to the healthy, in whom they brought forth disease. Volatile contagions were transmitted by the atmosphere. He maintained that a contagion was a living - "and, indeed, endowed with individual life"-material that had a parasitic relationship to the sick body. He further declared that "smallpox-pus is pus and smallpox-contagion, plague-pus is pus and plague-contagion". But no explanation is offered as to how diseases that arose "miasmatically" could also spread by contagion. Nor, as he claimed in a later publication, ${ }^{17}$ how a miasm could develop from the crowding together of those affected by a contagion. Although Henle maintained that miasmatic diseases could develop contagions and vice versa, he conceded that a miasm-"i.e. that which contaminated"-was little more than a concept, and that it was not possible to say to which of the natural kingdoms it belonged or, indeed, whether it belonged to any of them.

So much for the "noteworthy attempt to dispel the miasmatic fog" of Underwood!

The contention of Fildes and McIntosh, endorsed by Bulloch, that Koch's postulates (which Koch himself had renounced by 1884$)^{18}$ were in truth those of Henle was supported by a partial English translation from Pathologische Untersuchungen. But this translation was tendentious, in that it omitted elements that weakened the argument. The following is a full translation of the relevant passage, in which the omissions of Fildes and McIntosh are given in italics and their different translations of certain expressions in brackets:

If one finds living, motile, animalcules or distinct plants in contagious materials, it is possible, as also in laudable pus, as in all animal secretions, that they are there accidentally, if the materials

17 J. Henle, Handbuch der rationellen Pathologie. Specieller Theil, Braunschweig, F. Vieweg u. Sohn, Bd. 2, 1851.

${ }^{18}$ By renouncing the necessity of producing experimental infections in animals as a proof that his comma bacillus was the cholera pathogen. R. Koch, 'Ueber die Cholerabakterien', Dtsch. med. Wschr., 1884, 10: 191-192. 


\section{Fracastoro and Henle}

have been exposed for some time to air. And even if they are found constantly and within the body in contagious materials, it would always be possible to raise the objection, hardly to be refuted, that they are merely parasitic even though constant elements of contagions, as some still say of the semen-animalcules [spermatazoa in semen]-elements that develop in the fluid, and may even be of diagnostic significance, without being the active material of the fluid or of the semen. Whether they are really the active material [principle] could only be decided empirically if the semen-animalcules [spermatazoa] and seminal fluid, the contagion-organisms and contagion fluid were to be isolated, and the power of each could be separately observed [tested] - an experiment that must no doubt be renounced.

There is no doubt that the above passage implies the hypothesis, unsupported by any observations or experiments, that the active elements of contagions might be living organisms. As has already been noted, Henle had no suggestion to offer as to what might be the nature of miasms, although he believed that there could be a transmutation from them to contagia in certain circumstances and vice versa. The question to be considered is to what extent Henle's conceptions were original, and to what extent they merely represented a reshuffling of ideas that had been current for some years. It is interesting that he was not even sure whether the spermatazoon was the active element of semen.

\section{IDEAS OF CONTAGION BEFORE HENLE}

The extent to which Henle's hypotheses are to be regarded as original, and constituting a breakthrough, can only be judged by reference to typical examples of ideas that had already been expressed before 1840 .

In the seventeenth century, Thomas Sydenham's conception of contagion was that "particles of the atmosphere . . . first insinuate themselves amongst the juices of the body, disagree with them, mix themselves up with the blood; and, finally, taint the whole frame with the contagion of the disease." He agreed that a "pestilential virus" or "murderous miasma" played a role in plague, in addition to "atmospheric variations", but would not allow that the "virus" alone could transmit the disease for, if this were the case, "deaths would succeed deaths in one continuous and indefinite series". ${ }^{10}$ It is to be noted that for Sydenham changes in the atmosphere and miasmata were not synonymous, although he gave no clue as to what he understood by "virus" and "miasma".

Richard Mead, in his well-known discourse of 1720 on pestilential contagion, referred indifferently to "contagious matter", "infectious matter", or "seeds of contagion", comparing them to the scent of perfumes. ${ }^{20}$ The last of these terms might be thought to come closer than the seminaria of Fracastoro to implying an animate contagion, but Mead expressly rejected this idea: "some Authors have imagined Infection to be performed by the Means of Insects, the Eggs of which may be conveyed from Place to Place, and make the disease when they come to be hatched. As this is a supposition grounded upon no manner of Observation, so I think there is no need to have Recourse to it." Here Mead is loosely using the term "insects", as did many

\footnotetext{
10 Thomas Sydenham, The works of Thomas Sydenham, M.D. Translated from the Latin edition of Dr. Greenhill with a life of the author by R. G. Latham, M.D., London, Sydenham Society, 2 vols., 1848-1850.

${ }^{20}$ Richard Mead, $A$ short discourse concerning pestilential contagion, and the methods to be used to prevent it. London, S. Buckley, 1720.
} 


\section{Norman Howard-Jones}

much later authors, in the sense of micro-organisms. Although he did not believe in them, his negative statement shows that ideas of animate contagion were current at the time.

In the latter half of the eighteenth century, James Lind used the terms "infection" and "contagion" synonymously "to comprehend all fevers, of whatever kind, that are imparted from one person to another". He stated that the "seeds of infection" were "strongly adhesive" to bed linen, wearing apparel, furniture, and utensils, and that: "By the source of an infection I mean those seeds of contagion expressed by the Greek appellation miasmata" [in Greek characters in the original]. ${ }^{21}$

Of particular interest as giving a cross-section of views on contagion and infection in 1819 are the hearings of a British Parliamentary Select Committee appointed "to consider the validity of the doctrine of contagion in plague". ${ }^{22}$ Of twenty-five medical witnesses heard, all but two "were in favour of the received doctrine that Plague is a disease communicated by contact only, and different in that respect from Epidemic fever", one of the witnesses stating that contagion and infection were in many cases synonymous, but that the former "should be more properly confined to a somewhat, capable of separate or self-existence, and of propagating its species ad infinitum, through its operation on the human body." He added that "contagion" did not "in common language imply actual contact", and cited the example of smallpox.

When Asiatic cholera first invaded Russia in 1830, rapidly spreading to Poland, Prussia and Austria, controversy between contagionists and noncontagionists became much intensified, as did discussions among the former as to the nature of contagion. Before cholera had reached England or France, Sir Gilbert Blane in 1831 published a pamphlet warning the British people of the impending danger and exhorting them to protect themselves by temperate habits. ${ }^{23}$ Defining his terms, he wrote, "The epithets contagious and infectious I employ as synonymous; but I avoid the use of both as much as possible, and comprehend them both under the term communicable." 24 Blane was convinced that cholera was contagious, but did not define either infection or contagion.

Across the channel, and at about the same time, Moreau de Jonnès advised the Higher Council of Health of France that cholera was "incontestably" contagious, and that a contagion was "a principle sui generis, a germ ... that posseses the power to develop and reproduce itself in the manner of organized beings, and which propagates itself by mediate or intermediate transmission from a sick to a healthy individual." ${ }^{25}$ Here was not only an idea of an animate contagion but also of its specificity. Also in 1831, A. Neale published a treatise in support of "the Linnaean doctrine of

21 Lind, op.cit., note 16 above.

${ }^{22}$ Great Britain, House of Commons, Report from the select committee appointed to consider the validity of the doctrine of contagion in plague, [London, 1819].

${ }^{23}$ Sir Gilbert Blane, Warning to the British public against the alarming approach of the Indian cholera, [London] November 1831. (A new impression "with a few additions" referring to the invasion of England by cholera since the original impression was published. Pamphlet No. 30888 bound in Pamphlet Volume 591 of the National Library of Medicine, Bethesda, Md.)

"As far as I am aware, this was the first use of the term "communicable" in this sense, and it was not in general use until many years later.

${ }^{25}$ A. Moreau de Jonnès, Rapport au conseil supérieur de santé sur le cholera-morbus pestilentiel . . ., Paris, de Cosson, 1831. 


\section{Fracastoro and Henle}

animate contagion". ${ }^{26}$ In this he expressed his conviction that diseases were conveyed by "some substance or substances endued with life, perhaps also with motion, and in all probability, minute living microscopical objects, or some zoophytical creatures or polypuses."

When cholera reached the German States in 1831, the founder of homoeopathy, Samuel Hahnemann, published an "appeal to thinking friends of humanity" in which he unequivocally maintained that the disease was transmitted by a "miasm probably consisting of innumerable invisible living organisms". He believed that these organisms had the power of reproduction. ${ }^{27}$ In a pamphlet published in 1832, an anonymous non-medical author came extraordinarily close to a correct explanation of the etiology and epidemiology of cholera, in speaking of small aquatic insects ${ }^{28}$ which were "introduced into the stomach, either through the medium of liquids or food". ${ }^{29}$ This author cited in support of his hypothesis Redi's experiments disproving the spontaneous generation of maggots and insisted that "the food itself" was not the cause of cholera but "the medium through which the cause is introduced into the human constitution". He advised that where there was a danger of cholera "water should always be boiled" and that "no food should be eaten which is not cooked or hot". He also proposed as a test of his hypothesis an inquiry as to "whether any instances occur of persons having contact with cholera patients, but who have neither ate nor drunk within the infected quarter, have been attacked." Here was a virtually complete, although entirely speculative, theory of cholera etiology and prophylaxis.

Also in 1832, Professor E. D. A. Bartels of Berlin asserted that a contagious or infectious substance (Ansteckungsstoff) could be transmitted from a sick to a healthy person, producing the disease in the latter. ${ }^{30} \mathrm{He}$ distinguished between miasms and contagions, dividing the latter into "fixed" and "volatile". While contagious diseases were communicable, miasmatic diseases were not, although the latter might in certain circumstances develop a contagion, thus becoming communicable. All these ideas were repeated by Henle eight years later. Bartels, however, rejected the concept of "miasmatic-contagious" diseases.

By 1832 the idea that specific contagious diseases were caused by specific germs was sufficiently current to warrant the derision of François Magendie, who in one of his lectures mocked the notion that "men cleverer than us" thought that the origin of cholera was a germ. ${ }^{31}$ Such men, he said, "Know even the different types, for they have classified them into five different species: those of oriental plague, those of cholera, those of leprosy, those of yellow fever, and those of typhus ...". As a final dig, Magendie told his students that there were countries in which "the government

\footnotetext{
" A. Neale, Researches to establish the truth of the Linnaean doctrine of animate contagions ...., London, Longman etc., 1831.

"Samuel Hahnemann, Anruf an denkende Menschenfreunde über die Ansteckungsart der asiatischer Cholera, Leipzig, Carl Berger, 1831. (On the verso of the title-page, the publisher thanks the author for having provided his MS free of charge!)

${ }^{28}$ Again, in the context of the period, "insects" should be interpreted as "micro-organisms".

20 An enquiry into the remote cause of cholera, Edinburgh and London, 1832. (Pamphlet No. 89279 bound in Pamphlet Volume 1040 of the National Library of Medicine, Bethesda, Md.)

${ }^{30}$ E. D. A. Bartels, Cholera-Archiv, 1832, Bd. 1, Ht. 1, pp. 27-35.

:1 François Magendie, Leģons sur le choléra-morbus faites au Collège de France, Paris, MequignonMarvis, 1832.
} 


\section{Norman Howard-Jones}

does not look upon you with a favourable eye if you are not a partisan of the doctrine of contagion (laughter)". The laughter of these misguided students was to echo for more than half a century. Magendie's anticontagionism is noteworthy, for he has a strong claim to be regarded as the pioneer of experimental medicine. A year before Henle's treatise appeared, Sir Henry Holland published a volume of essays which included one "On the hypothesis of insect life as a cause of disease". In this he posed the question whether some epidemic and contagious diseases were "derived from minute forms of animal life . . acting as a virus on the living body". ${ }^{32} \mathrm{He}$ supported this hypothesis by reference to the finding by microscopical examination of "animalcules (vibriones) in syphilitic pus" and "a minute worm (trichina spiralis)" in muscle. Holland dismissed the idea of "epidemic constitutions" as a "phrase which wraps ignorance in the garb of scientific language". He maintained that the spread of cholera could be explained only by a "faculty of reproduction" of the cause, and that this must be a function of "animal life".

\section{CONCLUSIONS}

Fracastoro's ideas on contagion were obscure, clouded with superstition, and bore no realistic relation to present knowledge of communicable diseases. The importance of his speculations has been grossly exaggerated. Charles Singer came much nearer the truth when he said that Fracastoro's "conception bore a superficial resemblance to the modern germ theory of disease."

As for Henle, his essay represents little more than a reformulation of ideas that had been widely ventilated for some years. His only original notion was that of isolating "contagion-organisms" from "contagion fluid" to test which of them was the active agent in communicable diseases. But this idea is much weakened by the reservations that this would be "an experiment that must no doubt be renounced" [my italics]. Henle's classification of what we now know as communicable diseases into "miasmatic", "miasmatic-contagious" and "contagious" confused rather than clarified the understanding of them.

The speculations of both Fracastoro and Henle have been the object of an immoderate and uncritical adulation that is entirely unmerited.

\footnotetext{
32 Henry Holland, Medical notes and reflections. London, Longman, etc., 1839.

s Charles Singer, $A$ short history of medicine, Oxford, Clarendon Press, 1928.
} 